保健物理, 44 (2), $209 \sim 217$ (2009)

資 料

\title{
東海再処理施設における排水中の超ウラン核種等に関する調査
}

\author{
河野 恭彦*1, 檜山 佳典*1, 中野 政尚*1, 武 石 稔*1
}

(2009 年 3 月 18 日受理)

(2009 年 5 月 7 日再受理)

\section{Survey of Transuranium Nuclides in Low Level Liquid Effluents from the Tokai Reprocessing Plant}

\author{
Takahiko Kono, ${ }^{* 1}$ Yoshinori HiYAma, ${ }^{* 1}$ Masanao NAKANO*1 and Minoru TAKeISHI ${ }^{* 1}$
}

We surveyed the concentration levels of Transuranium (TRU) nuclides in the effluent discharged from the Tokai Reprocessing Plant (TRP) from 1998 to 2003 for Light Water Reactor (LWR) Fuel Reprocessing. The survey was performed for upcoming the effluent monitoring in Fast Breeder Reactor (FBR) Fuel Reprocessing. It was confirmed that the TRU nuclides concentration discharged from the TRP was $1 / 150 \sim 1 / 10^{6}$ much lower than the concentration limits authorized in governmental notification. Then, we compared the normalized discharge amounts by the unit of generated energy from the TRP with those from the foreign reprocessing plants. As a result, the TRP has reduced the amounts of discharged nuclides, by the order of $1 / 100-1 / 10^{7}$ compared with foreign ones. This survey provided the important and basic data in order to compare the effluent of TRU nuclides in FBR and the present nuclear fuel cycles.

KEY WORDS: Transuranium (TRU) Nuclide, Minor Actinide (MA), Radiochemical Analysis, low level liquid effluents, Fast Breeder Reactor (FBR) cycle, Normalized Discharge Amount, Reprocessing, ORIGEN, Radioactivity Ratio.

\section{I 緒言}

東海再処理施設は，使用済核然料中に含まれるウラ ン（U）及びプルトニウム（Pu）を新たな燃料として有 効利用するために，ピューレックス法によって，U 及び $\mathrm{Pu}$ を抽出する施設である。ピューレックス法とは使用 済核然料を硝酸で溶解後，TBP（トリブチルリン酸）— ドデカンを用いた溶媒抽出等を行い, 核燃料物質と核分 裂生成物を分離する方法である。この過程で生じる液体 廃棄物のうち, 高・中レベル廃液は施設内に貯蔵される が, 中レベル廃液を処理した凝縮液や, 放射線防護衣等 の洗濯や機器等の除染などの雑廃液等の低レベル廃液を 処理した後の廃液は, 液体廃衰物として海洋に放出され

*1 (独) 日本原子力研究開発機構核燃料サイクル工学研究所; 茨城県那珂郡東海村村松 4-33（ ₹ 319-1194）

Nuclear Fuel Cycle Engineering Laboratories, Japan Atomic Energy Agency; 4-33 Muramatsu Tokai-mura, Naka-gun, Ibaraki 319-1194, Japan.
る。このときの放出量は, 当研究所の再処理施設保安規 定に定められる放出基準值を超えないように管理されて いる。また施設周辺の住民の線量当量は, 年間約 0.022 $\mathrm{mSv}$ と評価されている。この評価結果は, 再処理事業 指定申請書に基づいて評価された気体・液体廃棄物の環 境放出の合計で年間約 $0.018 \mathrm{mSv}$, さらにスカイシャイ ン $\gamma$ 線を加えたものであり, 公衆の線量限度 $1 \mathrm{mSv}$ に比 べて十分に低い。

海洋放出される液体廃棄物のモニタリング（以下,「排 水モニタリング」と記す）では, 主な核種 $\left({ }^{3} \mathrm{H},{ }^{90} \mathrm{Sr}\right.$, ${ }^{129} \mathrm{I},{ }^{137} \mathrm{Cs}$ 等 $)$ の他, $\mathrm{Pu}(\alpha)\left({ }^{238} \mathrm{Pu},{ }^{239,}{ }^{240} \mathrm{Pu}\right.$ の和）の $\alpha$ 線放出核種についても測定が行われている。ただし，Pu 以外の $\alpha$ 線放出核種は, その濃度レベルが低いので, 核 種毎ではなく， $\alpha$ 線放出核種の全放射能量（全 $\alpha$ 放射能） として測定，管理がなされている。

しかし， ウラン資源の有効な利用を進めるためには高 速増殖炉サイクルが必要である ${ }^{1)}$ 。高速増殖炉サイクル においては, 混合酸化物燃料を高燃焼度で利用すること 
から，これまで東海再処理施設で処理してきた低濃縮ウ ラン燃料処理時に比べて, 使用済燃料中にマイナーアク チニド（MA; Minor Actinide）核種を含めた TRU 核種の 含有量が多くなる。このため, 排水放出管理上, MA 核 種を含めた TRU 核種のモニタリングは極めて重要にな ると考えられる。また，これらの核種は実効線量係数が 大きく, 環境へ多量に放出された場合には, 公衆の線量 評価上においても重要となる。よって, 排水中のこれら の核種の濃度, 放出量を把握することが必要となってく る。

そこで今回の調查では, 高速増殖炉燃料再処理時の放 出管理に向けた前段階として, 軽水炉燃料再処理時にお ける排水中 TRU 核種等の濃度確認を行うために, 下記 の $1 \sim 3$ を行った。

1. 供試量を可能な限り増やし, 検出限界值を下げる ことで, 通常の放出モニタリングで $\mathrm{Pu}(\alpha)$ として 合算している ${ }^{238} \mathrm{Pu},{ }^{239,}{ }^{240} \mathrm{Pu}$ を別々に取り扱い，ま た全 $\alpha$ 放射能として一括管理している ${ }^{237} \mathrm{~Np}$ 及び ${ }^{241} \mathrm{Am}$ といった TRU 核種の濃度レベルを調査する。 さらに ${ }^{99} \mathrm{Tc}$ は, 比較的実効線量係数が大きく，ま た半減期も長いため, 環境への影響が懸念されるこ とから，TRU 核種と合わせて調査する。

2. 取得した東海再処理施設の上記核種の放出量を, 使 用済燃料が発電した電力量で規格化することによっ て, 海外再処理施設と放出量を比較する。

3. 東海再処理施設の実測值の妥当性を確認するため に, 燃焼計算コードによる燃料中の放射能比と, 再 処理施設内に㧍ける除染係数から, 排水中の放射能 比を算出し，実測値と比較する。

軽水炉燃料再処理時の排水中濃度把握は, 混合酸化物 燃料再処理時の濃度を解釈する上での参考資料になると 考えられる。また今回の調査で, 必要となる TRU 核種 等の検出限界值が明確になり, 合理的に TRU 核種等の 供試量を設定することが出来る。

\section{II 分析・解析方法}

\section{1. 調査期間及び調査対象核種}

今回の調查対象核種は, ${ }^{238} \mathrm{Pu},{ }^{239} \mathrm{Pu},{ }^{240} \mathrm{Pu},{ }^{241} \mathrm{Pu}$, ${ }^{241} \mathrm{Am},{ }^{237} \mathrm{~Np},{ }^{99} \mathrm{Tc}$ の 4 元素 7 核種である。ただし ${ }^{239} \mathrm{Pu}$ と ${ }^{240} \mathrm{Pu}$ は， $\alpha$ 線スペクトロメトリーでは $\alpha$ 線のエネル ギーが近接しており分離できないため, 合算した值（ま とめて ${ }^{239,240} \mathrm{Pu}$ と記す）として求めた。

調査期間は 1998 年 4 月〜 2004 年 3 月の 6 年間である。 今回の調查期間において, 前半の 1998 年 4 月〜 2000 年
3 月の 2 年間は, 計画停止のため, 再処理施設の処理運 転は行われなかった。その後, 2000 年 4 月〜 2004 年 3 月の 4 年間は, 再処理施設の運転が行われている。

\section{2. 合成試料作製方法}

東海再処理施設から排水を海洋放出する際, 放出前に 排水を一旦タンクに貯留する。タンク内の排水を均一に 摚拌し, 当研究所放射線管理部で害施している排水の放 出判定分析により放出基準值を下回っていることを確認 した後, 貯留タンクから海中放出管を通して, 排水を沖 合 $3.7 \mathrm{~km}$ の海洋に放出している (バッチ放出)。

調査対象核種を分析するにあたり，各核種の供試量は 分析の処理が可能な量を考慮に入れて, 各核種の分析法 の検出下限值と予測される排水中放射能濃度から求め た。予測される排水中放射能濃度は，これまで試験的に 実施したTRU 核種を分析・測定してきた值を参考にし た。その結果, ${ }^{238} \mathrm{Pu},{ }^{239},{ }^{240} \mathrm{Pu}$ は $120 \mathrm{ml},{ }^{241} \mathrm{Pu}$ は $80 \mathrm{ml}$, ${ }^{241} \mathrm{Am}$ は $200 \mathrm{ml},{ }^{237} \mathrm{~Np}$ は $10,000 \mathrm{ml},{ }^{99} \mathrm{Tc}$ は 8,000 ml の 供試量が必要である。

上記の供試量を得るために, 複数のバッチから少しず つ排水を集めた。これは, 合成試料と呼ばれる。 ${ }^{238} \mathrm{Pu}$, ${ }^{239,240} \mathrm{Pu},{ }^{241} \mathrm{Pu},{ }^{241} \mathrm{Am}$ は月毎, ${ }^{237} \mathrm{~Np},{ }^{99} \mathrm{Tc}$ は四半期毎に, 各バッチの放出排水量に応じた合成試料をそれぞれ以下 の方法で作製した。

当該月, あるいは当該四半期に扔けるバッチ $\mathrm{k}$ の放出 水量を $\mathrm{V}_{\mathrm{k}}\left(\mathrm{m}^{3}\right)$, 核種 $\mathrm{i}$ の供試量を $\mathrm{W}_{\mathrm{i}}(\mathrm{ml})$ とすると,バッ 千試料 $\mathrm{k}$ からの核種 $\mathrm{i}$ の分取量 $\mathrm{B}_{\mathrm{i}, \mathrm{k}}(\mathrm{ml})$ は,

$$
B_{i, k}=\frac{V_{k}}{\sum_{k} V_{k}} \times W_{i}
$$

つまり

$$
W_{i}=\sum_{k} B_{i, k}
$$

となる。

\section{3. 分析手法}

排水中 $\mathrm{Pu}$ の分析法は,「核燃料サイクル工学研究所 標準分析作業法 放出管理編（以下，標準作業分析法）」22 及びY. Uezu et al. (2000) ${ }^{3)}$ に従った。しかし, Am, Np の分析法は標準作業分析法に記載されていないため, 文 部科学省「放射能測定法シリーズ」(以下, 測定法シリー ズ $)^{4)}$ を参考に，排水試料に適した分析法に改良した。 上記の測定法シリーズは環境試料を対象とした分析法で ある。環境試料はマトリックスや夾雑物が多いが, 今回 の調査で取扱う排水試料は蒸発処理等を経たものであ り, 不純物がほとんど含まれていないため, 環境試料で 行う分析ほど他元素の除去を行う必要がない。そこで当 
研究所では，今回の調査で用いる排水試料が環境試料ほ どの前処理は必要ないことから, 測定法シリーズの前処 理の工程を短縮して, $\mathrm{Am}, \mathrm{Np}$ の排水分析を行った。なお, Tc に関しては M. TAKEISHI et al. (2005) ${ }^{5)}$ に従い, 分析を 行った。それぞれの核種の分析法は以下の通りである。

(1) ${ }^{238} \mathrm{Pu},{ }^{239,}{ }^{240} \mathrm{Pu}$ 及び ${ }^{241} \mathrm{Pu}$ 分析

分析フローを Fig. 1 に示す。供試料 $200 \mathrm{ml}$ に分析回 収率補正用トレーサーとして ${ }^{242} \mathrm{Pu}$ を約 $0.1 \mathrm{~Bq}$ 添加後, 蒸発乾固し, 硝酸, 過塩素酸で有機物分解を行った。 次に硝酸系の陰イオン交換樹脂（DOWEX1×8［100$200 \mathrm{mesh}]$ ）に $\mathrm{Pu}$ を吸着させ，U 等の他元素を取り除い てから, ヨウ化水素酸で Pu を四価から三価に還元し, 樹脂から溶離した。溶離液を蒸発乾固し, 塩酸で加熱溶 解して放冷後, メスフラスコに移し, 蒸留水で $20 \mathrm{ml}$ に 定容した。その溶液を $3: 2$ に分け, ${ }^{238} \mathrm{Pu},{ }^{239,240} \mathrm{Pu}$ は 12

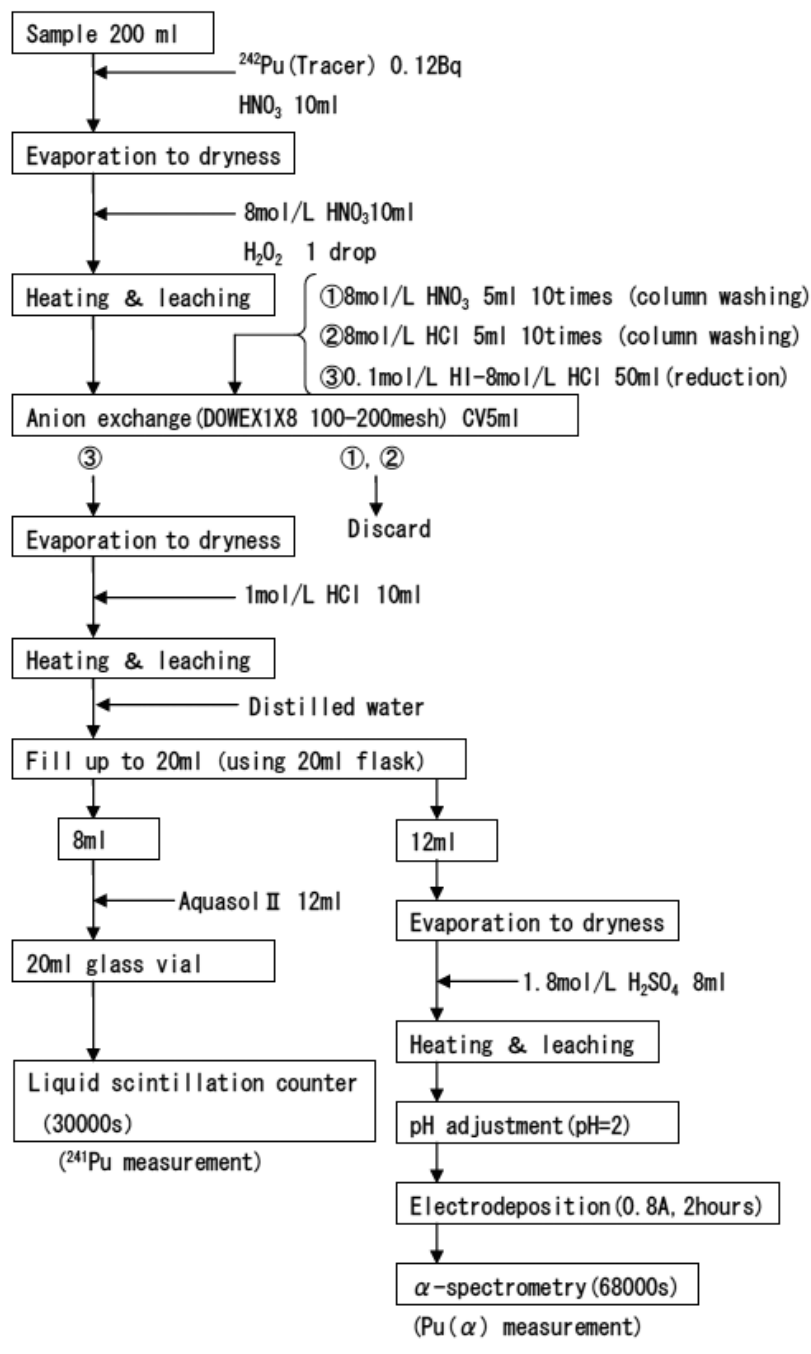

Fig. 1 Analytical flow of $\mathrm{Pu}(\alpha)$ and ${ }^{241} \mathrm{Pu}$ in effluents. $\mathrm{ml}$, 軟 $\beta$ 線を放出する ${ }^{241} \mathrm{Pu}$ は $8 \mathrm{ml}$ に供して, 以下の分 析を行った。

前者は, 溶液を蒸発乾固し, 硫酸で加熱溶解, 放冷後, $\mathrm{pH}$ を調整し, 電着セルに少量の水を用いて移した。あ らかじめ $0.1 \mathrm{~mol} / \mathrm{L}$ 硝酸で洗浄した直径 $24.5 \mathrm{~mm}$ のステ ンレス製の電着板をセットした直流電着装置を用いて, DC $0.8 \mathrm{~A}$ で 2 時間通電し， $\mathrm{Pu}$ を電着した。さらに，電 着セルを電着装置から取り外す前にアンモニア水を 2 3 滴加え, 1 分間通電した。電着板を赤外線ヒーターに 焼き付けて放冷後, シリコン半導体検出器に接続した $\alpha$ 線波高分析装置 $\left(\mathrm{Si}\right.$ 半導体検出器 有感面積 $450 \mathrm{~mm}^{2}$ 検 出器系, EG \& G ORTEC) で 68,000〜80,000 秒測定した。 測定で得られた ${ }^{238} \mathrm{Pu},{ }^{239},{ }^{240} \mathrm{Pu}$ それぞれの計数率を $\mathrm{Si}$ 半 導体検出器の計数効率, 供試量 $120 \mathrm{ml}$ で除して, ${ }^{238} \mathrm{Pu}$ と ${ }^{239,240} \mathrm{Pu}$ の放射能濃度を求めた。

後者は, $20 \mathrm{ml}$ ガラスバイアルにホールピペットで $8 \mathrm{ml}$

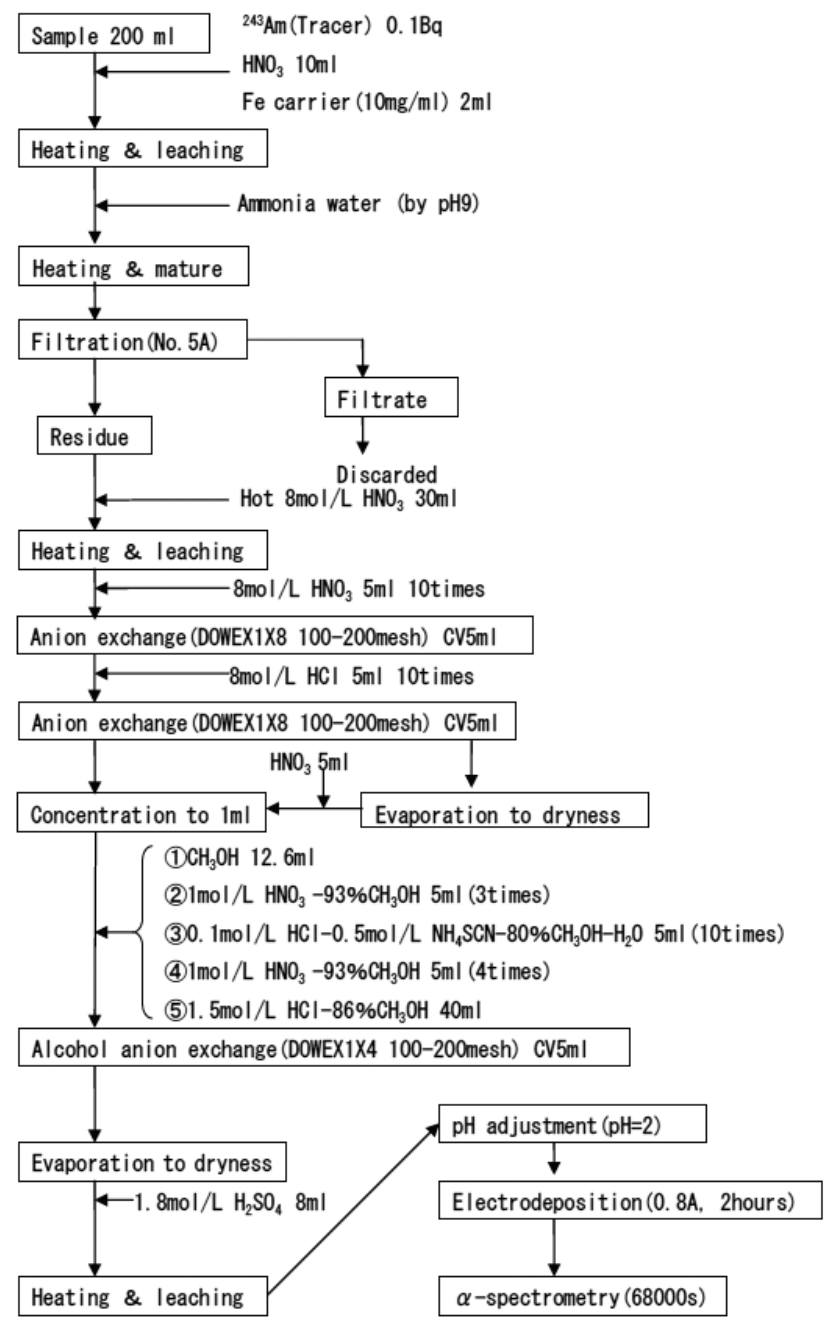

Fig. 2 Analytical flow of ${ }^{241} \mathrm{Am}$ in effluents. 
分取し，アクアゾル II を $12 \mathrm{ml}$ 加えた後，ガラスバイア ルを湯浴で加温し，良く撹拌して均一にさせた。ガラス バイアル試料を液体シンチレーションカウンタ（Wallac 1414）にセットし, 試料中の化学発光が収まるまで約 2 時間置いた後, ${ }^{241} \mathrm{Pu}$ の $\beta$ 線を 30,000 秒測定した。

検出限界值は, ${ }^{238} \mathrm{Pu}$ 及び ${ }^{239,}{ }^{240} \mathrm{Pu}$ が約 $3.7 \times 10^{-5} \mathrm{~Bq} / \mathrm{cm}^{3}$, ${ }^{241} \mathrm{Pu}$ が約 $6.0 \times 10^{-4} \mathrm{~Bq} / \mathrm{cm}^{3}$ である。

(2) ${ }^{241} \mathrm{Am}$ 分析

分析フローを Fig. 2 に示す。供試料 $200 \mathrm{ml}$ に分析回 収率補正用トレーサーとして ${ }^{243} \mathrm{Am}$ を約 $0.1 \mathrm{~Bq}$ 添加後, 鉄担体 $20 \mathrm{mg}$ 加え, 煮沸させた。そこへ水酸化鉄（II） 沈殿が生じるまでアンモニア水を加え, 沈殿が生じた 後, 加温熟成させ, No. $5 \mathrm{~A}$ 万紙でろ過した。沈殿物を 硝酸で溶解させた。放冷後, 硝酸系の陰イオン交換樹脂 （DOWEX $1 \times 8$ [100-200 mesh]）に通液し, Th, Puか ら Am を分離した。分離した溶液は, 蒸発乾固後, 塩酸 で加熱溶解させた。放冷後, 塩酸系の陰イオン交換樹脂 (DOWEX $1 \times 8$ [100-200 mesh]）により Fe, U を樹脂 に吸着させ, Am を分離した。蒸発乾固後, 濃硝酸を加

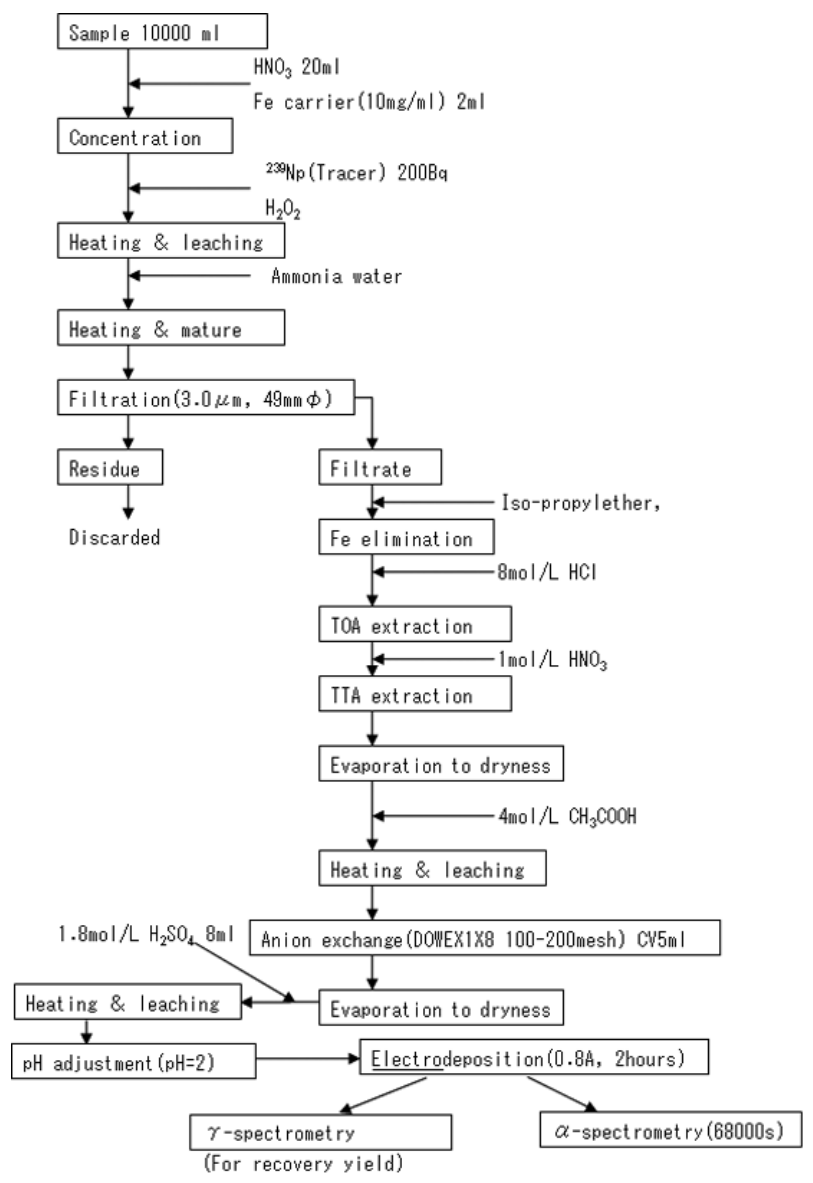

Fig. 3 Analytical flow of ${ }^{237} \mathrm{~Np}$ in effluents.
え加熱溶解, 濃縮し, メタノールを加え, アルコール系 の陰イオン交換樹脂 $($ DOWEX 1×4 [100-200 mesh]) で, まず Am を樹脂に吸着させつつ, 溶液中の希土類元素と チオシアン酸イオン（陰イオン交換の試薬で使用）を取 り除いてから, Am を溶離した。Am 溶離液を蒸発乾固 させ, 硫酸で加熱溶解し, $\mathrm{pH}$ 調整後, 前述した $\mathrm{Pu}$ 分析 と同様に電着した。電着後, シリコン半導体検出器を用 いた $\alpha$ 線スペクトロメトリーにより， ${ }^{241} \mathrm{Am}$ を測定した。 測定時間は $68,000 \sim 80,000$ 秒, 検出限界值は約 $1.0 \times$ $10^{-5} \mathrm{~Bq} / \mathrm{cm}^{3}$ である。

(3) ${ }^{237} \mathrm{~Np}$ 分析

分析フローを Fig. 3 に示す。供試料 10,000 ml に硝酸, 鉄担体 $20 \mathrm{mg}$ を加え, サンドバス上で $1,000 \mathrm{ml}$ まで濃 縮させた。分析回収率補正用トレーサーとして, ${ }^{243} \mathrm{Am}$ からミルキングした ${ }^{239} \mathrm{~Np}$ を約 $200 \mathrm{~Bq}$ 添加し, 過酸化 水素水を加え, 加熱煮沸させた。そこへ水酸化鉄（II） 沈殿が生じるまでアンモニア水を加え, 沈殿が生じた 後, 加温熟成させ, メンブレンフィルター（孔径 $3.0 \mu \mathrm{m}$, 直径 $49 \mathrm{~mm}$ Millipore）でろ過した。沈殿物を温塩酸で

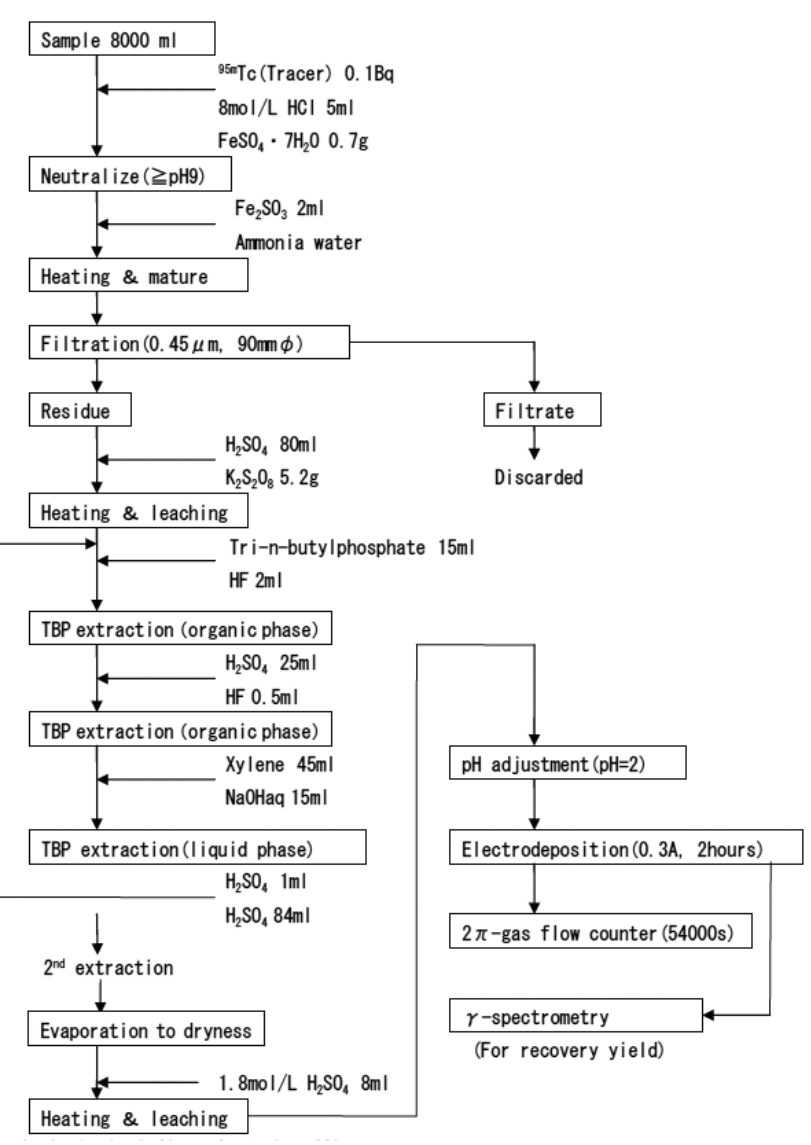

Fig. 4 Analytical flow of ${ }^{99} \mathrm{Tc}$ in effluents. 
Table 1 Annual averaged radionuclides concentration in the TRP's effluents from 1998 to 2003

\begin{tabular}{|c|c|c|c|c|c|c|c|}
\hline \multirow{2}{*}{$\begin{array}{c}\text { Fiscal } \\
\text { year }\end{array}$} & \multirow{2}{*}{$\begin{array}{l}\text { Discharged } \\
\text { amounts }\left(\mathrm{m}^{3}\right)\end{array}$} & \multicolumn{6}{|c|}{ Annual averaged concentration $\left(\mathrm{Bq} / \mathrm{cm}^{3}\right)$} \\
\hline & & ${ }^{238} \mathrm{Pu}$ & ${ }_{239,240} \mathrm{Pu}$ & ${ }^{241} \mathrm{Pu}$ & ${ }^{241} \mathrm{Am}$ & ${ }^{237} \mathrm{~Np}$ & ${ }^{99} \mathrm{Tc}$ \\
\hline 1998 & 11,150 & $3.0 \times 10^{-5} \pm 4.1 \times 10^{-6}$ & $1.3 \times 10^{-5} \pm 2.7 \times 10^{-6}$ & $5.2 \times 10^{-4} \pm 1.2 \times 10^{-4}$ & $1.3 \times 10^{-5} \pm 1.9 \times 10^{-6}$ & $5.4 \times 10^{-8} \pm 1.3 \times 10^{-8}$ & $1.2 \times 10^{-6} \pm 1.8 \times 10^{-7}$ \\
\hline 1999 & 14,409 & $3.1 \times 10^{-5} \pm 3.6 \times 10^{-6}$ & $1.2 \times 10^{-5} \pm 2.3 \times 10^{-6}$ & $5.5 \times 10^{-4} \pm 1.1 \times 10^{-4}$ & $1.1 \times 10^{-5} \pm 1.9 \times 10^{-6}$ & $8.3 \times 10^{-8} \pm 1.3 \times 10^{-8}$ & $8.3 \times 10^{-6} \pm 2.6 \times 10^{-7}$ \\
\hline 2000 & 28,986 & $6.6 \times 10^{-5} \pm 7.0 \times 10^{-6}$ & $2.8 \times 10^{-5} \pm 4.4 \times 10^{-6}$ & $1.3 \times 10^{-3} \pm 1.3 \times 10^{-4}$ & $2.1 \times 10^{-5} \pm 2.8 \times 10^{-6}$ & $3.8 \times 10^{-8} \pm 9.7 \times 10^{-9}$ & $2.1 \times 10^{-5} \pm 3.6 \times 10^{-7}$ \\
\hline 2001 & 38,785 & $7.7 \times 10^{-5} \pm 6.2 \times 10^{-6}$ & $3.4 \times 10^{-5} \pm 4.9 \times 10^{-6}$ & $1.5 \times 10^{-3} \pm 1.2 \times 10^{-4}$ & $1.3 \times 10^{-5} \pm 2.4 \times 10^{-6}$ & $3.1 \times 10^{-8} \pm 1.0 \times 10^{-8}$ & $1.4 \times 10^{-5} \pm 3.2 \times 10^{-7}$ \\
\hline 2002 & 28,819 & $1.2 \times 10^{-4} \pm 8.4 \times 10^{-6}$ & $5.6 \times 10^{-5} \pm 6.7 \times 10^{-6}$ & $2.5 \times 10^{-3} \pm 1.4 \times 10^{-4}$ & $2.3 \times 10^{-5} \pm 2.8 \times 10^{-6}$ & $6.2 \times 10^{-8} \pm 1.1 \times 10^{-8}$ & $9.0 \times 10^{-6} \pm 2.2 \times 10^{-7}$ \\
\hline 2003 & 27,547 & $1.3 \times 10^{-4} \pm 7.6 \times 10^{-6}$ & $6.5 \times 10^{-5} \pm 5.1 \times 10^{-6}$ & $3.1 \times 10^{-3} \pm 1.5 \times 10^{-4}$ & $1.7 \times 10^{-5} \pm 2.1 \times 10^{-6}$ & $4.4 \times 10^{-8} \pm 1.2 \times 10^{-8}$ & $5.8 \times 10^{-6} \pm 2.1 \times 10^{-7}$ \\
\hline \multicolumn{2}{|c|}{ Concentration } & $4.0 \times 10^{-3}$ & $8.0 \times 10^{-3}(* 2)$ & $2.0 \times 10^{-1}$ & $5.0 \times 10^{-3}$ & $9.0 \times 10^{-3}$ & $1.0 \times 10^{0}$ \\
\hline \multicolumn{2}{|c|}{$\left.\operatorname{Limit}^{(6)}\right)$} & & & & & & \\
\hline
\end{tabular}

(*1) Error was calculated from standard deviation of monthly or quarterly averaged concentration.

(*2) The concentration limit of ${ }^{239,240} \mathrm{Pu}$ is sum of those of ${ }^{239} \mathrm{Pu}$ and ${ }^{240} \mathrm{Pu}$.

溶解後, 溶液を分液ロートに入れ，イソプロピルエーテ ルとの溶媒抽出により，溶液中の鉄を取り除いた。次に トリ-n-オクチルアミン（TOA）との溶媒抽出, そして 硝酸と 2 テノイルトリフルオロアセトン（TTA）キシレ ンの溶媒抽出により, 溶液中のUを分離させた。その 後, 酢酸系の陰イオン交換樹脂（DOWEX $1 \times 8$ [100$200 \mathrm{mesh}]$ ) により, まず溶液中に残る Uを分離してから, $\mathrm{Np}$ を溶離させた。溶離液を蒸発乾固させ, 硫酸で加熱 溶解後, $\mathrm{pH}$ 調整し, 前述した $\mathrm{Pu}$ 分析と同様に電着した。 電着後, シリコン半導体検出器を用いた $\alpha$ 線スペクトロ メトリーにより， ${ }^{237} \mathrm{~Np}$ を測定した。測定時間は 600,000 秒，検出限界值は約 $5.0 \times 10^{-8} \mathrm{~Bq} / \mathrm{cm}^{3}$ である。なお，分 析回収率は $\mathrm{Ge}$ 半導体検出器 (高純度 $\mathrm{Ge}$ 半導体検出器, EG \& G ORTEC) で ${ }^{239} \mathrm{~Np}$ のピークを定量して求めた。

\section{(4) ${ }^{99} \mathrm{Tc}$ 分析}

分析フローを Fig. 4 に示す。供試料 $8,000 \mathrm{ml}$ に分析回 収率補正用トレーサーとして ${ }^{95 \mathrm{~m}} \mathrm{Tc}$ を約 $0.1 \mathrm{~Bq}$ 添加し, 塩酸, 硫酸鉄 - 七水和物, 塩化鉄（II）を加え, 沈殿が 生じるまでアンモニア水を良く擋拌させながら加えた。 （ここで水溶液中の Tc は， Tc（VII）から Tc（II）に還 元され，水酸化鉄（II）に共沈される。）加温熟成後, 沈殿物をメンブレンフィルター（孔径 $0.45 \mu \mathrm{m}$, 直径 90 mm Millipore）でろ過した後, 沈殿物を硫酸で洗浄し, 過硫化カリウムを加え, 加熱溶解させた。放冷後, (1) $200 \mathrm{ml}$ 分液ロートに移し, TBP $15 \mathrm{ml}$, フッ化水素 $2 \mathrm{ml}$ を加え, 3 分間振とうし, 10 分間放置後, 水相を取り除 いた。(2)硫酸 $25 \mathrm{ml}$, フッ化水素酸 $0.5 \mathrm{ml}$ を加え, 振と うさせ, 5 分間放置後, 水相を取り除いた（2)の操作を $2 \sim 3$ 回繰り返す)。(3)キシレン $45 \mathrm{ml}$, 水酸化ナトリウ 厶溶液（約 8 重量％） $15 \mathrm{ml}$ を加え, 3 分間振とうさせ,
10 分間静置後，水相を別の $200 \mathrm{ml}$ 分液ロートに移し, 濃硫酸 $1 \mathrm{ml}$, 硫酸 $84 \mathrm{ml}$ 加え, 再び(1)〜(3)の抽出操作を 繰り返した。2 回目抽出作業が終了後, 逆抽出液（水相） を電着セルに移し, 少量の蒸留水を加え, 電着装置にセッ トした（DC 0.3 A で 2 時間通電）。電着セルを電着装置 から取り外す前にアンモニア水 $2 \sim 3$ 滴加え, 1 分間通 電した。赤外線ヒーターに焼き付けて放冷後, $2 \pi$ ガス フローカウンタ (LBC 480, ALOKA) で ${ }^{99} \mathrm{Tc}$ を測定した。 測定時間は, 54,000 秒, 検出限界值は約 $1.0 \times 10^{-6} \mathrm{~Bq} / \mathrm{cm}^{3}$ である。なお, 分析回収率は $\mathrm{Ge}$ 半導体検出器で ${ }^{95 \mathrm{~m}} \mathrm{Tc}$ の ピークを定量して求めた。

\section{4. 年度放出放射能及び年度平均濃度算出方法}

年度間の放出放射能量は, 排水試料の分析結果に当該 試料の放出水量を乗じて算出した。また, 年度平均濃度 は，上記で求めた年度間放出放射能量を年度間の放出水 量で除して算出した。年度放出放射能量及び年度平均濃 度算出方法の詳細な算出方法は, 下記の通りである。

ある月あるいはある四半期の合成試料中の核種 $\mathrm{i}$ の濃 度を $\mathrm{C}_{\mathrm{i}}\left(\mathrm{Bq} / \mathrm{cm}^{3}\right), \mathrm{j}$ 月あるいは第 $\mathrm{j}$ 四半期の放出水量を $\mathrm{V}_{\mathrm{j}}\left(\mathrm{cm}^{3}\right)$ とすると, 核種 $\mathrm{i}$ の年度放出放射能 $\mathrm{A}_{\mathrm{i}}(\mathrm{Bq})$ は, 式（3）により求められる。

$$
A_{i}=\sum_{j}\left(C_{i} \times V_{j}\right)
$$

また年度平均濃度 $\mathrm{D}_{\mathrm{i}}\left(\mathrm{Bq} / \mathrm{cm}^{3}\right)$ は式 (4)により求められる。

$$
D_{i}=\frac{A_{i}}{\sum_{j} V_{i}}
$$

\section{III 結果及び考察}

\section{1. 年度平均放射能濃度及び放出放射能}

東海再処理施設における 1998 ～ 2003 年度の各核種の 


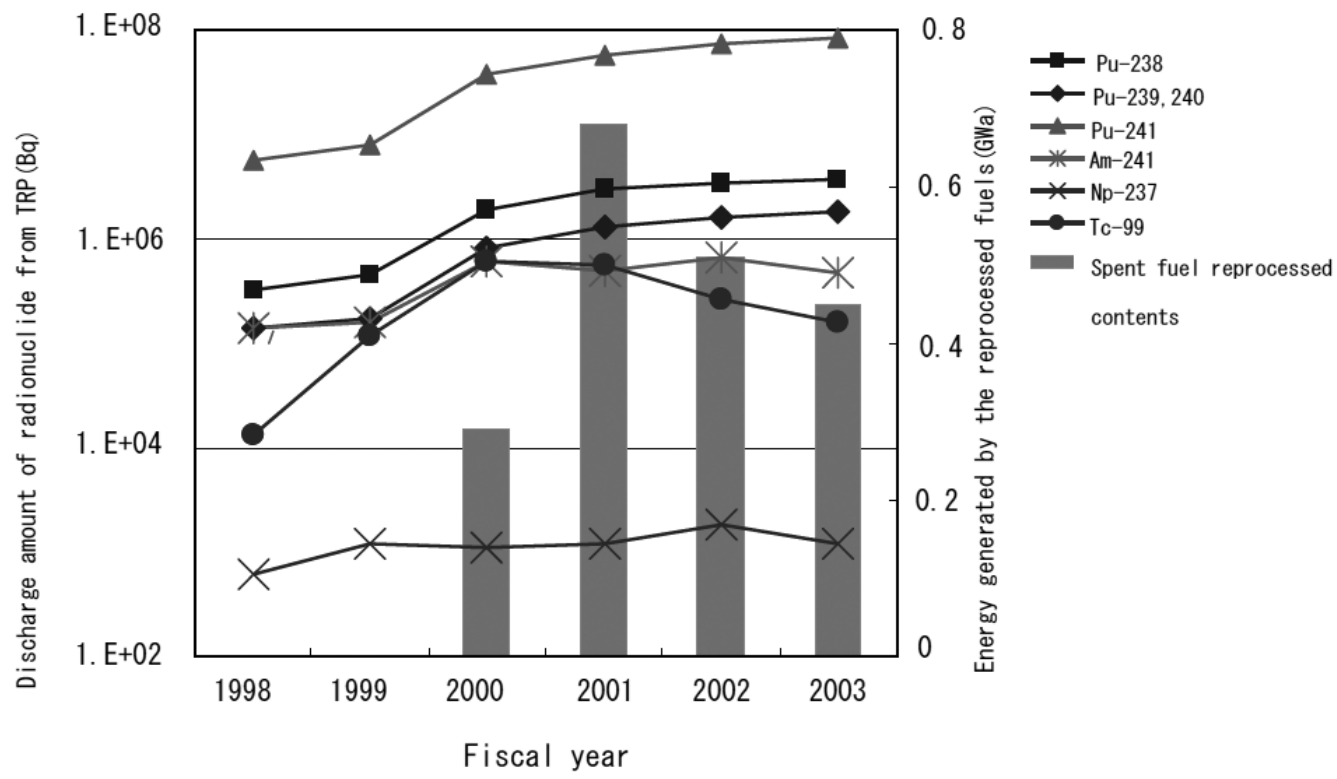

Fig. 5 Discharge amount of radionuclides from the TRP and the energy generated by the reprocessed fuels.

年平均放射能濃度を告示別表の排水中濃度限度 (第 6 欄)

6) と合わせて, Table 1 に示す。Table 1 では, 主に統計 変動による計数不確かさ（標準偏差）の 3 倍を誤差とし て示している。各核種の年平均放射能濃度は次の通りで あった。

$$
\begin{aligned}
& { }^{238} \mathrm{Pu}: 3.0 \times 10^{-5} \sim 1.3 \times 10^{-4}\left(\mathrm{~Bq} / \mathrm{cm}^{3}\right) \\
& { }^{239,240} \mathrm{Pu}: 1.2 \times 10^{-5} \sim 6.5 \times 10^{-5}\left(\mathrm{~Bq} / \mathrm{cm}^{3}\right) \\
& { }^{241} \mathrm{Pu}: 5.2 \times 10^{-4} \sim 3.1 \times 10^{-3}\left(\mathrm{~Bq} / \mathrm{cm}^{3}\right) \\
& { }^{241} \mathrm{Am}: 1.1 \times 10^{-5} \sim 2.3 \times 10^{-5}\left(\mathrm{~Bq} / \mathrm{cm}^{3}\right) \\
& { }^{237} \mathrm{~Np}: 3.1 \times 10^{-8} \sim 8.3 \times 10^{-8}\left(\mathrm{~Bq} / \mathrm{cm}^{3}\right) \\
& { }^{99} \mathrm{Tc}: 1.2 \times 10^{-6} \sim 2.1 \times 10^{-5}\left(\mathrm{~Bq} / \mathrm{cm}^{3}\right)
\end{aligned}
$$

上記の各年平均濃度は告示別表 ${ }^{6)}$ に示される排水中濃 度限度に比べて, 約 1/150〜1/10 6 と極めて低いレベル であった。

また，式（3）によって求めた放出放射能量と, 発電 電力量に換算した燃料処理量の年度推移を Fig. 5 に示
す。 $\mathrm{Pu}(\alpha),{ }^{241} \mathrm{Pu},{ }^{241} \mathrm{Am},{ }^{99} \mathrm{Tc}$ は, 2000 年度からの再 処理施設の運転再開に伴い, 放出放射能の増加傾向が見

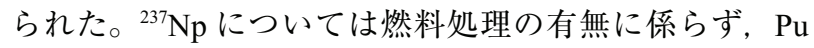
で見られたほどの増加傾向は認められなかった。一般的 に再処理施設で処理される軽水炉使用済燃料には， ${ }^{235} \mathrm{U}$ の核分裂により, 質量数が $80 \sim 140$ に渡る多くの核分 裂生成物や，原子炉内の核反応によって ${ }^{238} \mathrm{U}$ から生じ た ${ }^{239,240} \mathrm{Pu}$ などの $\mathrm{Pu}$ 同位体が多く含まれている。また 非常に微量ではあるが，中性子との核反応で生成された $\mathrm{Am}$ や $\mathrm{Cm}$ などの核種も含まれている7)。このことから も, 東海再処理施設の運転に伴い, $\mathrm{Pu}(\alpha),{ }^{241} \mathrm{Pu},{ }^{241} \mathrm{Am}$, ${ }^{99} \mathrm{Tc}$ の年放出量が上昇していると考えられる。しかし,

\begin{tabular}{|c|c|c|c|c|c|c|c|}
\hline \multirow{2}{*}{$\begin{array}{r}\text { Fiscal } \\
\text { year }\end{array}$} & \multirow{2}{*}{$\begin{array}{c}\text { Spent fuel } \\
\text { reprocessed } \\
\text { contents(GWa) }\end{array}$} & \multicolumn{6}{|c|}{ Normalized discharge amounts (GBq/GWa) } \\
\hline & & ${ }^{238} \mathrm{Pu}$ & ${ }^{239,240} \mathrm{Pu}$ & ${ }^{241} \mathrm{Pu}$ & ${ }^{241} \mathrm{Am}$ & ${ }^{237} \mathrm{~Np}$ & ${ }^{99} \mathrm{Tc}$ \\
\hline 1998 & 0 & & & & & & \\
\hline 1999 & 0 & & & & & & \\
\hline 2000 & 0.29 & $6.6 \times 10^{-3}$ & $2.8 \times 10^{-3}$ & $1.3 \times 10^{-1}$ & $2.1 \times 10^{-3}$ & $3.8 \times 10^{-6}$ & $2.1 \times 10^{-3}$ \\
\hline 2001 & 0.68 & $4.4 \times 10^{-3}$ & $1.9 \times 10^{-3}$ & $8.4 \times 10^{-2}$ & $7.4 \times 10^{-4}$ & $1.8 \times 10^{-6}$ & $8.2 \times 10^{-4}$ \\
\hline 2002 & 0.51 & $6.7 \times 10^{-3}$ & $3.1 \times 10^{-3}$ & $1.4 \times 10^{-1}$ & $1.3 \times 10^{-3}$ & $3.5 \times 10^{-6}$ & $5.1 \times 10^{-4}$ \\
\hline 2003 & 0.45 & $8.2 \times 10^{-3}$ & $4.0 \times 10^{-3}$ & $1.9 \times 10^{-1}$ & $1.1 \times 10^{-3}$ & $2.7 \times 10^{-6}$ & $3.6 \times 10^{-4}$ \\
\hline
\end{tabular}
${ }^{241} \mathrm{Am}$ (半減期 432.2 年, $\alpha$ 壊変）の壊変生成核種であ る ${ }^{237} \mathrm{~Np}$ は, その生成半減期が使用済燃料の貥蔵期間及 び今回の調查期間に比べ非常に長いことから, 調查期間 中ほとんど生成されなかったと考えられる。このことか

Table 2 Normalized discharge amounts of radionuclide from TRP from 1998 to 2003 
ら調査期間中において， ${ }^{237} \mathrm{~Np}$ の排水中放射能濃度はほ とんど変動しなかったと考えられる。

\section{2. 規格化放出量}

再処理の過程で発生する放射性廃棄物中の壊変生成物 や TRU 核種など放射能は，燃焼度 (GWa/t) やウラン 燃料処理量（t）に依存する。東海再処理施設と海外再 処理施設では，それぞれの施設における設計処理量が大 きく異なり, 例えば, 英国 British Nuclear Fuel Ltd (BNFL) のセラフィールド再処理施設では，その設計処理量が東 海再処理施設の約 6 倍である ${ }^{8)}$ 。そこで発生した電気エ ネルギーに換算した燃料処理量 ${ }^{9)}$ (電力量換算処理量 : 単位 $\mathrm{GWa}$ ）用いて, 海外再処理施設と比較すること とし, 放出放射能量を電力量換算処理量で除して算出す る規格化放出量 ${ }^{10)}$ を算出した。

まず，東海再処理施設における規格化放出量を Table 2 に示す。次に本規格化放出量と, 海外商用再処理施設で ある BNFL のセラフィールド再処理施設 ${ }^{8)}$ ，仏国 Areva $\mathrm{NC}$ (前 Cogema) 社のラ・アーグ再処理施設 ${ }^{11,12)}$ におけ る規格化放出量と比較した。その結果, 東海再処理施設 における調査対象各核種の規格化放出量は，英仏再処理 施設の約 $1 / 100 \sim 1 / 10^{7}$ と極めて低く，放出量の低減化 が図られていることを確認した（Fig. 6）。この違いは, 下記の 1）～2）が理由として考えられる。

1）東海再処理施設と海外再処理施設では放射性液体廃 裹物の処理方法が異なる。

2）再処理施設の放射性液体廃棄物の放出基準が異な
る。

まず1）について, 東海再処理施設は, 主に蒸発缶に よる蒸発処理によって放射性液体廃裹物を処理している ${ }^{13)}$ が, 海外再処理施設では, 主にイオン交換処理, 凝集沈 殿処理によって処理している。蒸発処理は，蒸発缶に熱 を加えて, 廃液を気化させるため, トリチウム $\left({ }^{3} \mathrm{H}\right)$ 等 の気化する放射性物質以外は効率的に取り除くことが出 来る。しかし, 凝集沈殿処理は蒸発処理に比べてエネル ギーはかからないものの, 化学試薬で放射性物質を沈殿 させてから，滤過装置で放射性物質を取り除くため，蒸 発処理より除染係数 (処理前の核種量を処理後の核種量 で除した数值)が小さい。ただし, 海外再処理施設も, 高・ 中放射性廃液に蒸発処理を取り入れ, さらなる放出量低 減化に努めている ${ }^{8,11)}$ 。東海再処理施設は, 燃料処理量 が少ないことから, 結果として東海再処理施設の廃液量 が諸外国の再処理施設より相対的に少なく，ほとんどの 放射性廃液の蒸発処理が可能であることから，規格化放 出量が小さくなったと考えられる。

次に2）について, 東海再処理施設と海外再処理施設 の全 $\alpha$ 放射能の放出基準值（海洋放出）を比較すると, 海外再処理施設の方が $10^{3} \sim 10^{4}$ 倍大きい $\left.8,10,11\right)$ 。海外 再処理施設は，これらの高い放出基準に基づく合理的な 放出管理を行っていることも, 規格化放出量が大きく異 なっている理由の 1 つと考えられる。

\section{3. 施設運転条件（情報）に基づく予測値との比較}

再処理施設内において, $\mathrm{Pu}, \mathrm{Am}, \mathrm{Np}$ は抽出分離, 精製,

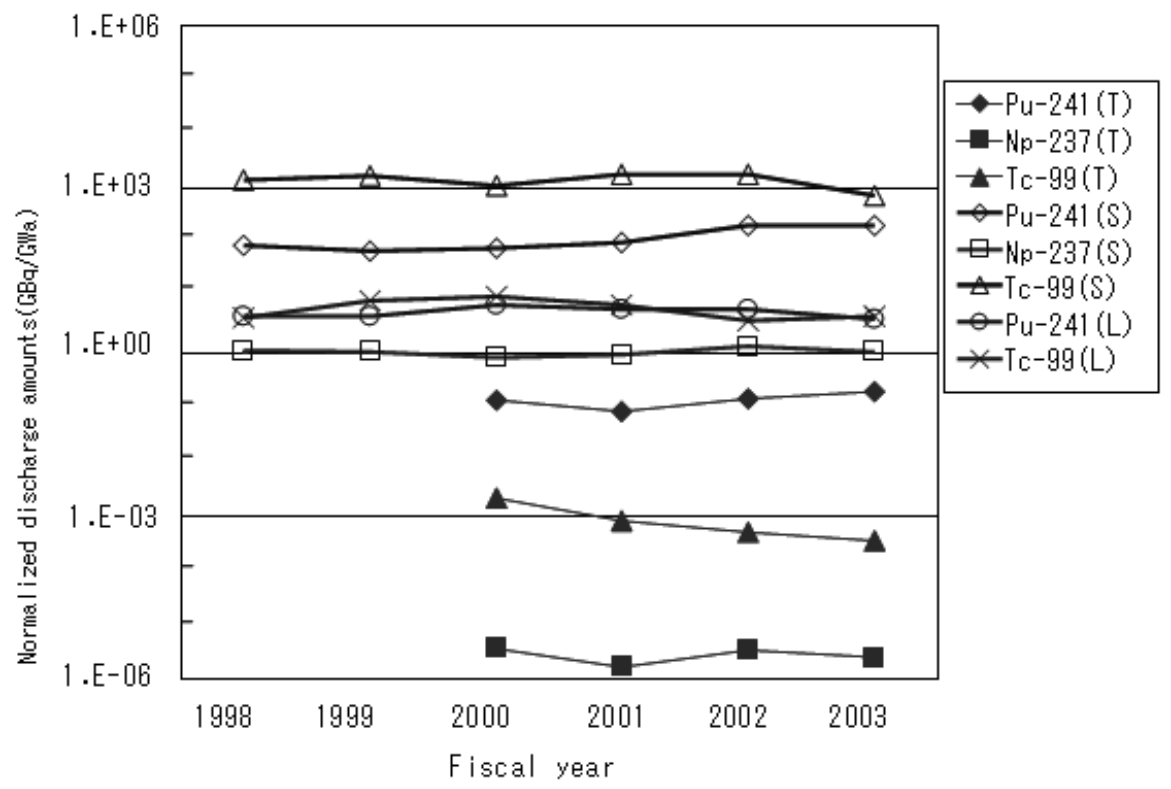

Fig.6 Comparison of the normalized discharge amounts among the TRP and the foreign reprocessing plants.

(*) T: TRP, S: Sellafield, L: La Hague. 
除染工程を経て，それぞれの化学的性質により分離され る。各工程において, 核種の分離性能を表す数值である 除染係数は既知であるので, 計算によって排水中に含ま れる核種の濃度レベルを推定することは可能であると考 えられる。そこで, 今回の調査で定量した排水中 TRU 核種の濃度の妥当性を確認するため, ORIGEN ${ }^{14)}$ と除染 倸数によって排水中の核種の放射能を求め, その值を実 測值と比較した。なお, ORIGEN とは, 米国オークリッ ジ国立研究所で開発された同位体の生成と消滅を計算す るコードである。比較にあたり，工程毎の排水の希釈等 の作業に, 依存されにくいパラメータである放射能比を 用いた。排水中の各核種間の放射能比と, ORIGENで 算出された使用済核燃料中の核種間の放射能比に, 工程 内の除染係数を乗じて求めた放射能比をそれぞれ求め, $2 つ の$ 值を比較した。なお今回の調查で用いた ORIGEN の主な計算条件は, 実際に処理した使用済燃料と同じで あり, 燃焼度 4,513〜34,056 ( $\mathrm{MWd} / \mathrm{t})$, 比出力 $16.3 \sim 34$ $(\mathrm{MW} / \mathrm{t})$, 冷却日数 $1,551 \sim 10,982$ (day) とした。計算 值と実測值の比較では使用済燃料の受入れから，低放射 性廃液の海洋放出までの除染係数を用いた。その值は $\mathrm{Pu}$ : 約 $5.3 \times 10^{14}, \mathrm{Am}$ : 約 $1.7 \times 10^{15}, \mathrm{~Np}$ : 約 $3.7 \times 10^{14}$ であ り, $\mathrm{Am}>\mathrm{Pu}>\mathrm{Np}$ である ${ }^{15)}$ 。

今回比較した核種間の放射能比は, ${ }^{238} \mathrm{Pu} /{ }^{239,240} \mathrm{Pu},{ }^{241} \mathrm{Pu} /$ ${ }^{239,},{ }^{240} \mathrm{Pu},{ }^{237} \mathrm{~Np} /{ }^{239}, 240 \mathrm{Pu},{ }^{241} \mathrm{Am} /{ }^{239}, 240 \mathrm{Pu}$ であり，それぞ れの值は良く一致した（Fig. 7)。ゅえに今回の調查の分 析值は，妥当な結果と考えられる。

なお，比較した核種間の放射能比の実測值及び ORIGEN と除染係数から求めた計算範囲は次の通りであ る。括弧内の值が ORIGEN の計算範囲を表す。

$$
{ }^{238} \mathrm{Pu} /{ }^{239,240} \mathrm{Pu}: 2.1 \sim 2.6(1.6 \sim 2.6)
$$

$$
\begin{aligned}
{ }^{241} \mathrm{Pu} /{ }^{239,}{ }^{240} \mathrm{Pu}: & 41 \sim 52(38 \sim 110) \\
{ }^{237} \mathrm{~Np} /{ }^{239,240} \mathrm{Pu}: & 4.2 \times 10^{-4} \sim 5.0 \times 10^{-3} \\
& \left(2.2 \times 10^{-4} \sim 6.1 \times 10^{-4}\right) \\
{ }^{241} \mathrm{Am} /{ }^{239,240} \mathrm{Pu}: & 0.86 \sim 4.5(1.8 \sim 3.2)
\end{aligned}
$$

\section{IV 結 論}

東海再処理施設において, 軽水炉燃料再処理時の排水 中 TRU 核種等の濃度, 放出量, 放射能比等を求めたと ころ, 以下の結果を得た。

1）東海再処理施設の排水中 MA 核種等を含む TRU 核 種の放射能濃度が, 告示に定められる濃度基準より 約 $1 / 150 \sim 1 / 10^{6}$ と十分低く管理されていることを 確認した。

2) 東海再処理施設の規格化放出量を, 海外再処理施設 と比較した結果, 東海再処理施設は今回の調查対象 核種に抢いて, 約 1/100 1/107 と十分な低減化が 図られていることを確認した。

3）今回の調査で得られた各核種の分析結果の妥当性 を確認するために, ORIGEN で算出された核種間 の放射能比に, 工程内の除染係数を乗じて求めた 放射能比との比較を行った。比較した ${ }^{238} \mathrm{Pu} /{ }^{239,240} \mathrm{Pu}$, ${ }^{241} \mathrm{Pu} /{ }^{239,}{ }^{240} \mathrm{Pu},{ }^{237} \mathrm{~Np} /{ }^{239},{ }^{240} \mathrm{Pu},{ }^{241} \mathrm{Am} /{ }^{239,240} \mathrm{Pu}$ は, 一 致した。したがって, 今回の調查の分析結果は妥当 であると考えられた。

今回の調查によって, 将来の高速増殖炉サイクルを考 慮した混合酸化物燃料の再処理に向け, 排水放出管理に 関する基礎的な比較デー夕を得ることができた。今後さ らに再处理施設の TRU 核種の詳細な濃度デー夕を得る ために，簡便で迅速な排水中 TRU 核種の分析法の開発 に取り組んでいく。

$(* 1)$

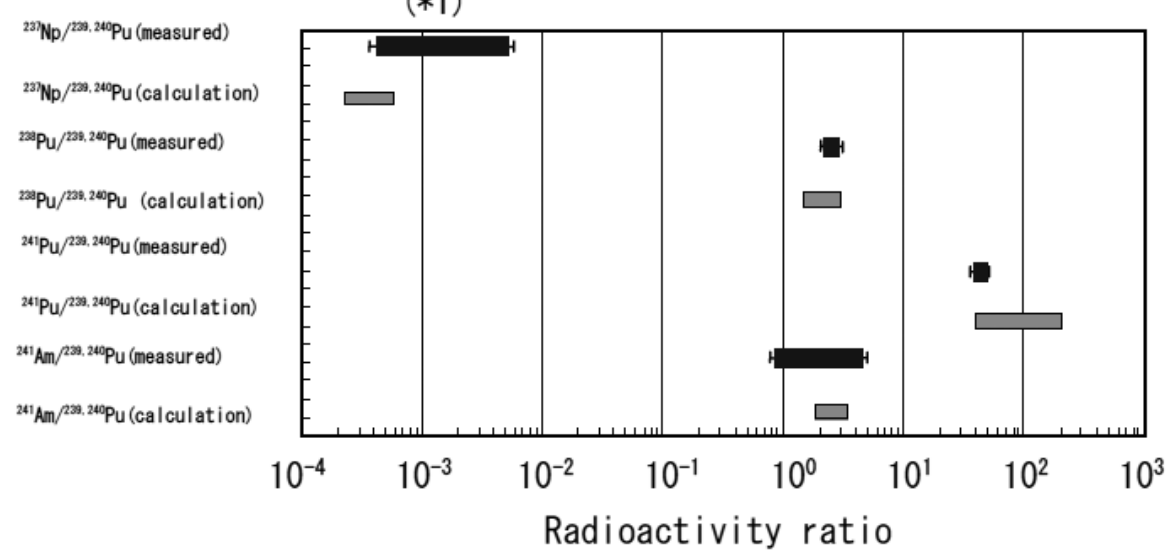

Fig.7 Comparison of the activity ratios by the measurements with those by the ORIGEN calculation $(* 1)$ The range of line in graph shows a error. 


\section{参 考 文 献}

1）内閣府原子力委員会: 原子力の研究, 開発及び利用 に関する長期計画 (2000).

2）桜井直行, 飛田和則, 吉崎裕一, 宮河直人, 山下朋 之, 柏崎涉, 植頭康裕; 動力炉核燃料開発事業団東 海事業所標準分析作業法放出管理編, PNC TN8520 93-003 (1993).

3) Y. Uezu, N. Miyagawa and H. Katagiri; Environmental ${ }^{241} \mathrm{Pu}$ Determination Using Alpha/Beta Distinguish Technique with Liquid Scintillation Measurement, IRPA10, p. 117 (2000).

4）文部科学省; 放射能測定法シリーズ, No. 28 環境試 料中プルトニウム迅速分析法 (2002)，No. 30 環境 試料中アメリシウム 241 (2004), No. 34 環境試料中 ネプツニウム 237 迅速分析法 (2008).

5) M. Takeishi, Y. Hiyama, T. Mizutani, H. Watanabe and Y. Maruo; Investigation of Analytical Method for Technetium-99 in Liquid Effluent Discharged from Tokai Reprocessing Plant, Jpn. Nucl. Radiochem. Sci., 5 (3), 265-266 (2005).

6）核燃料物質の加工の事業に関する規則等の規定に基 づき，線量限度等を定める告示，科学技術庁告示第 13 号 (2000).

7）（社）日本原子力学会；原子力がひらく世紀，p. 212 （1998），（株）東京印刷館（東京）。

8) BNFL; Discharges and Monitoring of the Environment in the United Kingdom Annual Report 2005, pp. 13-48 (2006).

9) UNSCEAR (United Nations Scientific Committee on the
Effects of Atomic Radiation); Exposures of the public and workers from various sources of radiation, United Nations, New York (2000).

$10 ）$ 水谷朋子, 宮河直人, 武石稔 ; 東海再処理施設にお ける液体廃棄物の放出モニタリングについて，サイ クル技報，28,21-25（2005）。

11) COGEMA; Inventaire des rejets radioactifs desinstallations nucleaires volume 1 (1999).

12) J. Simonnet; The minimization of radioactive release from the La Hague Plants, JAERI-Conf 96-003, 192, 180-181 (1995).

13）東海事業所再処理工場処理部化学処理第 2 課 ・廃棄 物処理課; 再処理工程の運転 7.2 放射性液体廃棄物, 動燃技報, 55, 36-40（1985）.

14) A. G. Croff; ORIGEN2-Isotope Generation and Depletion Code, ORNL/TM715 (1980).

15）大森栄一, 須藤俊幸, 清水武彦, 駿河谷直樹, 高谷 暁和, 小山暁, 中村博文, 槇彰, 山内孝道 ; 東海 再処理施設の安全性確認に係る基本データの確認, JNC TN8410 99-002 (1999).

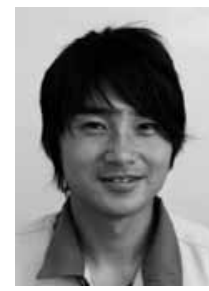

河野 恭彦（こうの たかひこ）

1982 年茨城県ひたちなか市生まれ。2006 年（独）日本原子力研究開発機構へ入社。 現在核然料サイクル工学研究所にて, 再 処理施設等の放出モニタリング，排水中 TRU 核種及び尿中ウランの迅速分析手法 の開発業務に従事。趣味はテニス，ドライブ，ジムに行 くこと，スポーツ観戦，スイーツ巡りなど。

E-mail: kono.takahiko@jaea.go.jp 